O 2020 The Author/s
This is an open access article under the terms of the CC-BY 3.0 License.
Peer review method: Double-Blind
Date of acceptance: May 25, 2020
Date of publication: August 14, 2020
Review article
DOI https://doi.org/10.47305/JLIA2020135z
UDC 327(520:510)
$327(520: 519)$
$341.7(520: 5)$

\title{
THE JAPANESE DIPLOMACY IN ASIA: EVOLUTION AND CHALLENGES
}

\author{
Georgios Zacharias \\ Sciences Po Paris, France \\ ORCID iD: https://orcid.org/0000-0003-4416-312X \\ georgios.zacharias@sciencespo.fr
}

\begin{abstract}
The diplomacy of Japan towards its Asian neighbours has always been a complex issue. Throughout the years, the foreign policy of Japan has witnessed severe alterations specifically after the Second World War. Since then, new challenges and opportunities have risen which have formed a new, adapted Japanese diplomacy, albeit not disconnected from its traditional aspects and its past. The current purpose of the paper is to highlight these evolutions and challenges of the post WWII Japanese diplomacy. The focus will be on the two main neighbours and traditional partners of Japan, the People's Republic of China and the Republic of Korea. There will be an effort to highlight the challenges that Japan experiences with the aforementioned countries, its diplomatic approaches and how these could be evolved in the near future.
\end{abstract}

Keywords: People's Republic of China; Republic of Korea; Japan; Diplomacy; History; Foreign Policy

\section{INTRODUCTION}

The Japanese diplomacy and foreign policy in Asia is a rather complex issue. Diplomacy could be rather defined as the constant pursuit of national interests and achievement of these objectives via peaceful means. However, as it always has been, factors such as the regional and international environment, the domestic political context, values and ideology, are heavily determining the diplomatic approaches of each country. Japan is no exception to that common rule. The Japanese diplomacy's historical background is full of alterations as it is evolving for hundreds of years. Until today at a certain extent, the 
traditional self-perception of the role of Japan in the region and subsequent challenges that follow it, still play a major role to the articulation of its foreign policy. Japan's openness to the world in the XIX century was a major event in terms of the diplomatic history of the country. Nevertheless, that does not mean that its foreign policy starts at that very moment. The Japanese diplomacy has deep roots into the past. Long traditional relationships with China and Korea for example, do exist long before the Meiji Restoration and the end of the Sakoku period, key historical events of the modern Japanese history associated with the analysis of the foreign relations of Japan. In fact, even at the isolation (Sakoku) period, the Tokugawa shogunate had established bilateral exchanges with China, Korea and the Dutch, proving that the diplomatic history of the country is much richer than it seems (Yasunori 2013). However, the focus of the current paper is not attached at the historical overview but instead it emphasizes on the current Japanese diplomacy in Asia. Short briefs and historical overviews will be made in order for the evolution and current challenges of Japan towards its neighbors to be better understood. The essay will be divided into two main chapters. The first one will be focusing on the Japanese diplomacy towards China, its long standing partner and rival with approximately two millenniums of bilateral engagement; The second one will emphasize in an another important player in the region, South Korea. The current paper will indicate and analyze the current diplomatic issues and challenges between Japan and its two significant counterparts, the main diplomatic approaches of the Japanese governments after the end of the World War II and its potential evolution at the near future.

\section{THE JAPANESE DIPLOMACY IN THE REGION}

First of all, before proceeding to the current case studies, some main key elements of the Japanese diplomatic framework in Asia must be noted. The traditional diplomacy of the country was always seeking recognition and understanding by its neighbors. That has driven its policy choices for a long time especially before World War II, when Japan considered itself to be responsible of leading Asia, as the main great power in the region. Its post war diplomatic approach varies in the way that Japan now portrays itself as the bearer of the international order in the region, pursuing its recognition as a provider of economic advancement and political stability in Asia (Kazuo 2015). That approach of course is a key point of friction with China due to the country's unprecedented economic and military rise.

In addition, as mentioned above, many factors also determine approaches at the foreign policy domain. As a result, the Japanese diplomacy is rather complicated. Firstly, there are the domestic factors. The rise of nationalism in Japan, public opinion and party politics are heavily influencing the foreign policy decision making. The political leaders, for instance, both in government and in opposition, are heavily engaged in the diplomatic domain, focusing on the sensitive diplomatic issues, sometimes even more than the MFA bureaucrats themselves (Wan 2016). Secondly, there is the external environment. The US-Japanese Security Treaty and alliance are shaping the responses of Japanese diplomacy in many cases 
regarding its bilateral relations, especially with China. When for example the Trump administration decided to prohibit purchases of the Chinese telecom giant Huawei, because of the current US-China trade war, Japan also re-regulated certain domestic rules regarding procurement procedures, in order to also exclude the Chinese firm (Wijaha and Yuma 2019). It is well understood that constraints on foreign policy choices do exist and the degree of external pressure, specifically by the US due to the significance of their bilateral relationship, is highly valued and calculated.

Third, the Japanese diplomacy is heavily value oriented. Identities and values play a major role at its shaping. Japan considers itself a democratic peaceful nation with a mature market economy, being an example in the East Asia/South East Asia region (Yoshimatsu 2012). This perception has driven Japanese diplomacy to reach other countries with similar value-sharing, such as Australia and India. The line of "shaping an arc of freedom and prosperity" as introduced by Abe's government in 2006, led to a series of negotiations and bilateral agreements, shaping in the mean time a more active diplomacy in contrast to the more passive approach which was adopted after the end of WWII (Yoshimatsu 2012). Examples of such agreements are first of all the 2007 Joint Declaration on Security Cooperation between Japan and Australia and the Japan-India Strategic and Global Partnership, which included 35 areas of cooperation specifically on the security domain (Wan 2016).

Fourth point of the diplomacy in Asia is its economic aspect. Economic diplomacy of Japan has always been the major tool of its foreign policy. Japan is pursuing its interests by securing economic benefits abroad, expanding its trade and investment capacity and providing at the same time financial and technical support to developing countries. Key historical moments of the country's economic diplomacy are the membership at the OECD in 1967, following its G7 membership in 1975. Furthermore, through its Official Development Assistance programs, Japan was and still is heavily expanding its influence mainly in the South East Asian countries, despite the fiscal deficits the country is facing. In 1997, Japan contributed more than 9 billion US dollars through the aforementioned program (Beaurdy and Cook 1999). It has also endorsed more than 20 concrete projects with the Mekong countries. Specifically, approximately 500 billion yen have been invested to official development assistance in Cambodia, Laos and Vietnam, a diplomatic measure aiming at countering China's influence in the region (Yoshimatsu 2012).

Last but not least, the unresolved issues of the past are a burden of Japan's foreign policy. History has long been interfering with the Japanese diplomacy, shaping at a large extent its bilateral relations in the region. The Yasukuni Shrine visits and the issue of Comfort Women, which will be presented in the parts that follow, are some example of these 'shadows' of the past that even after decades are still shaping the main foreign policy lines. These underlying issues make the bilateral relationships, especially with China and Republic of Korea, fragile and difficult to handle (Wan 2016). 
To conclude, taking into account the aforementioned approaches and challenges, the post war diplomacy of Japan has been structured under two main pillars that remain at the largest extent unchanged: Focus on the economic development; aversion to the use of military force. Japan, until now, has focused mainly at its economic growth relying for security on the United States (the post war Yoshida Doctrine), utilizing it at the same time as a diplomatic tool, declaring its pacifism and its respect for the universal values of freedom, democracy, human rights and the rule of law (Kowashima 2017). Even after the end of the Cold War, there is a strong urge for Japan to become a 'normal' state and even if some progress towards becoming a stronger political and military actor in the region has been made, these main basic approaches still exist.

Lastly, another major pillar has been added, that of the 'Free and Open Indo-Pacific'. Japanese diplomacy is heavily engaging to this strategy in order to protect its interests, especially in the maritime area. It is referring mainly to the protection of trade and shipping lanes in a geographical area including the Asia-Pacific region to Middle East (Japanese MFA 2019). More specifically, the strategic objectives of Japan, according to the Diplomatic Book of 2019, include the promotion and establishment of free trade and the rule of law in the region, pursuing in the mean time economic prosperity and peace. These objectives are overall interpreted as the evolution of the Japanese diplomacy from an overall passivity to a more active role trying to consolidate its interests in the region of Asia and beyond.

\section{THE JAPANESE APPROACH TOWARDS CHINA}

Besides the general trends of Japanese diplomacy as indicated above, which dominate the foreign policy thinking of the post war era, China is an interesting case study indicating different approaches and challenges regarding Japan. The bilateral relationship could be safely characterized as complicated with a lot of positive aspects and disputes. An improvement started to appear with the normalization of their bilateral relationship which came in 29 September 1972. Then, the following period of 1982-1990, when China found itself isolated due to the Tiananmen Square incident, was cleverly exploited by the Japanese diplomacy in order to enhance their bilateral relationship. Sharply thinking, Japan achieved both pleasing its western counterparts by contributing to sanctions in China and also appeared as a bridge between the latter and the West (Wan 2016). Overall today, the Japanese diplomacy is focusing on three principles towards China as expressed by the Prime Minister in 2018: shifting to collaboration and not competition; being partners instead of threats; achieve a free and fair trade (Wijaya and Yuma 2019). The economic diplomacy of Japan is heavily focusing on the cooperation and expansion towards China achieving today an unprecedented interaction. More specifically, the two countries represent approximately more than 15\% of global GDP, with China being established as the second strongest economic power, surpassing Japan, pulling more than a billion people out of underdevelopment (Meyer 2011). 
According to the Japanese MFA, the two countries are characterized by "close economic relations", since there are vast numbers of Chinese tourists traveling to Japan, large trade imports and exports and people to people exchanges. It is indeed well noted that their trade numbers of imports and exports were approximately 1 billion US dollars in 1972 when the normalization of their diplomatic relationship took place. In 2014, the same trade figures touch 312,4 billion US dollars (Wan 2016). This excessive economic interdependence that has been created the last decades is a crucial factor shaping leadership's decisions in the foreign policy of both countries.

However, the main issues of their bilateral relationship have not been resolved. The Japanese social thinking, and as a result its foreign policy approach, views China as a rival and a threat. Consequently, their relationship remains controversial in political, historical and security aspects (Kuwashima 2017). The main issues that still exist today are first, the Senkaku/Diaoyu dispute, ${ }^{1}$ second, Taiwan, and third, the 'shadows' of the past. Historical issues concerning the imperialistic past of Japan and war crimes towards its neighbors is intensely political challenging the Japanese diplomacy through the years. Other minor issues still exist such as the issue of chemical weapons which have been discarded in Chinese territory and the Kokaryo dispute which refers to a Tokyo student dorm that is not yet decided if it belongs to China or Taiwan (Wan 2016). ${ }^{2}$

Regarding the Senkaku dispute, the country's policy makers were focusing on the usage of diplomatic bargaining and the utilization of international norms (Yoshimatsu 2012). In the specific case, the main diplomatic response adopted for years was laying aside the issue and changing the focus on other domains of cooperation. The basic foreign policy approach was following the 'Middle Line' policy in the East China Sea, something that China does not accept and participating with China in the joint development of the Shirakaba gas field found in the area (Wan 2016). However, that slightly changed after the regime transition in 2009 when the Democratic Party (DPJ) took over the power. The general economic context of the financial crisis that heavily affected Japan was also a negative factor. But the key event that triggered the dispute and tested Japanese diplomacy was the fishing boat collision of 2010 (McCurry 2010). The decision of the DPJ leadership to arrest the captain of a Chinese fishing boat, which collided with the Japanese vessel near the Senkaku islands, was signaling a new approach to the dispute: there is no recognized territorial dispute in the area and the collision is treated as a domestic affair in a Japanese territory (Wan 2016). The upcoming

\footnotetext{
${ }^{1}$ The Senkaku (in Japanese)/Diaoyu (in Chinese) dispute is referring to the country's territorial dispute regarding an island chain in the East China Sea between the two countries. Both China and Japan claim the islands and the surrounding area as their own territory for historical and economic reasons since research has shown that the seabed around the islands is rich in gas and oil reserves.

2 The Kokaryo dispute is referring to a student dorm which was created in the University of Kyoto in Japan for Chinese students in 1945. The Nationalist government of China, which fled to Taiwan after the end of the civil war, purchased the dorm from its Japanese owner in 1952. In the decades to come, Taiwan followed legal actions in order to evict students from the mainland China even if Japan has recognized Beijing as the legitimate government. The legal battle and different rulings continue until today with diplomatic repercussions for Japan itself, especially regarding towards its relationship with Taiwan.
} 
nationalization of the islands by the following government in 2012 provoked massive unprecedented demonstrations in China, bringing their relationship to the lowest point since the normalization.

Japan's diplomacy has as a result changed for the first time regarding the issue, getting harsher and away from its past practices. The following 2012 LDP victory in national elections approved that change and the overall foreign policy towards China became rigorous as a response to the nationalistic Japanese sentiment. The diplomatic trend from that point onwards was the following: strengthening the US-Japan alliance; allowing the Japanese military to operate outside its borders under specific circumstances; promote international cooperation in defense R\&D; counter the rise of China by seeking and creating new alliances (Wan 2016).

Regarding the historical issues, they are found again in the front row of the foreign policy challenges. The end of the Koizumi administration was characterized by a short period of calmness regarding the issue, with a foreign policy line of holding no visits to the Yasukuni Shrine. That changed along with the emergence of the disputes in the East China Sea and Prime Minister's Abe visit to the Shrine in 2013. The temple is considered to be, by Japan's neighbors, as the main symbol of the Japanese imperialism and military past. The prime ministers' visits throughout the years, was seen as paying homage to Class A war criminals enshrined there who were the main contributors to the Japanese war crimes and colonialist past (Kazuo 2015). ${ }^{3}$ The official diplomatic approach of Japan expressed by its Prime Minister Abe after his visit, is that the Shrine should not become a political issue and the purpose of the visit is to "pledge that Japan will never wage war again" and to "report before the souls of the dead" how the country's administration is advancing (Prime Minister of Japan Statements 2013).

Lastly, the third main challenge of the Japanese diplomacy is Taiwan. Japan has been heavily interested on the issue especially since the 90s, recognizing its high significance. The Taiwan Strait is the route for strategic shipping lanes to Southeast Asia and Middle East, being a vital key area for the Japanese national interests (Wan 2016). As a result, the relations between Taiwan and Beijing are of high interest for Japan. In the mean time, any alteration of the relationship between the two or between Taipei and Tokyo has an impact on the bilateral approach of China forming an interconnected political 'triangle'. The official Japanese position regarding the confrontation between China and Taiwan remains unchanged since 1972. Japan, in the Joint Statement of 1972 that normalized its relations with Beijing, accepted the 'One China Principle' encouraging in the mean time "a peaceful resolution of issues concerning Taiwan Strait through dialogue" (Wan 2016).

\footnotetext{
${ }^{3}$ The Yasukuni Shrine is a Shinto temple in Tokyo founded in 1869, honoring those who died for the country listing mainly names of the dead. Unfortunately, among the almost two million names there are around a thousand convicted war criminals. For that reason, official visits of the Prime Minister or the Emperor provoke reactions to the neighbor countries, accusing Japan of honoring its imperialistic past and its atrocities by paying homage to the names of the criminals.
} 
The Japanese diplomacy accepts that principle, refusing however the adoption of the "Three No's" policy, as adopted by China (Wijaya and Yuma, 2019). ${ }^{4}$

\section{THE JAPANESE DIPLOMACY TOWARDS SOUTH KOREA}

South Korea, or else the Republic of Korea (ROK), could also be a perfect example showing the complexity of the Japanese foreign relations. On the one hand, ROK is forming a political strategic 'triangle' with Japan and the United States creating a firm alliance in Northeast Asia, in order to protect their common interests against the Chinese military and economic rise and North Korea's nuclear threat. On the other hand, Japanese diplomacy is struggling to keep some balance in the bilateral relationship with their main ally in the region. A number of issues between the two make the cooperation and mutual trust extremely difficult and complicated. The main challenges are the issue of Comfort Women, ${ }^{5}$ the Yasukuni Shrine visits, history textbooks, the Takeshima/Dokdo territorial dispute ${ }^{6}$ and the "Sea of Japan" name dispute (Kimura 2019).7

It is important to stress out that since the establishment of their diplomatic relations in 1965, their relationship today has reached an all time low. The language on the Japanese Diplomatic Bluebook of the 2019 is rather strict on the description of their bilateral relationship. Taking into account that in previous diplomatic statements the ROK was characterized as "important neighbor" with "extreme close relations" that "share the same values" (MoFA 2010) or more recently as an "important neighbor" who "shares strategic interests" with Japan (MoFA 2016), the current rhetoric is rather different. Today the main statement to begin with in order to describe the relationship and diplomatic approach of Japan, is that their relationship "face an extremely severe situation" blaming indirectly the ROK's leadership for that evolution (MoFA 2019). Beginning with the main issues, the Takeshima case and the 'Sea of Japan' name dispute, the Japanese diplomacy possess a strict approach. It does not recognize any dispute, firmly stating that Takeshima Islands are a part of Japanese territory as well as claiming that the internationally accepted name of the maritime region under question stands as 'Sea of Japan'. The statements from the Ministry of Foreign Affairs also mention that "historical facts" and the "International Law" are supporting Japan's position, that the Sea of Japan is the "only international established name" and more

\footnotetext{
4 The 'Three No's' is a policy adopted from China towards Taiwan that characterizes its basic approach towards it: No independence of Taiwan, No to 'two Chinas' or 'one China and one Taiwan' and No to the membership of Taiwan in organizations with the status of a state.

${ }^{5}$ As 'comfort women' are characterized women and girls who were used as sex slaves by the Japanese army in occupied territories during the Second World War, mainly in the Korean Peninsula. There is different perception between South Korea and Japan regarding if the issue is permanently resolved.

${ }^{6}$ The Takeshima (in Japanese) / Dokdo (in Korean) is an island chain that both countries claim as their own territory. It is a similar case as the Senkaku/Diaoyu one, as presented above.

${ }^{7}$ The Sea of Japan is a maritime area between Japan, Russia and the Korean Peninsula. South and North Korea have raised objections towards the international name and the former country argues that the current name became common when Korea was under Japanese rule.
} 
or less the Japanese diplomacy indirectly accuses the South Korean leadership of making efforts to rewrite the history between the two countries (Ryall 2019). The landing of members of the ROK's National Assembly on the Takeshima Islands, as well as the military exercises that took place there, have deteriorated the situation (Yamasaki 2016).

Nevertheless, the rest of the challenges are not less significant. The different historical perceptions are still on the discussion table and aggravate the public opinion in both countries as well as augment their nationalistic sentiments. Regarding the issue of Comfort Women, Japan has indeed participated in discussions with the Republic of Korea achieving a bilateral agreement and the establishment of a taskforce to review its implementation (Kimura 2019). According to the Japanese diplomacy, the issue is finalized and "irreversibly closed" blaming the South Korean leadership of creating more claims regarding the issue and trying to reform the agreement (MoFA 2019). The ROK's initiative of building 'comfort women statues' in front of the Japanese Embassy in Seoul, triggered stricter reactions where Japan denied any further negotiations on the issue, declaring the official closure of the bilateral agreement and accusing ROK for deteriorating their relationship (Kimura 2019). Regarding the issues of history textbooks and the Yasukuni Shrine, the problem is the same as explained in the previous chapter. South Korea has adopted the same position as China towards these issues, considering them as symbolic moves of Japan of honoring its imperialistic past and colonialism era. The Japanese diplomacy has refused the allegations made, as already mentioned in previous pages.

\section{CONCLUSION}

The Japanese diplomacy in Asia is apparently multifaceted. As it happens with all sovereign states, some foreign policy lines remain strictly untouchable when others are more adaptable to change. The Japanese diplomacy in Asia is a mixture of these two elements. Issues concerning Senkaku and Takeshima are not discussable but in other domains, such as the issue of the Comfort Women, changes have been made trying to find a common ground. As indicated throughout the paper, the main policy lines Japanese diplomacy use, are at a large extent attached and dependent to the US foreign policy choices as well as other past practices. Being more specific, regarding the Sino-Japanese relationship, the first case study of the paper, the Japanese diplomacy faces difficulties in order to find alternative approaches. The Senkaku/Diaoyu dispute seems to be impossible to be resolved in the near future. China has already surpassed Japan in nominal GDP terms and its military rise has established the country as a regional and international great power that will not accept a compromise. Japan, will also not. The 'Middle Line' policy option, which Japan provided China regarding East China Sea, splitting the maritime region in half, has not been accepted by China. Two facts must always be kept in mind as well. First, nationalistic sentiments are not going to be diminished in either of the two countries; second, historical burdens will still exist since neither of the two countries seems to be eager to participate in sensitive historical discussions. 
Also taking into consideration how public opinions shape foreign policies at a significant extent, it is more likely that the current status quo will remain as such.

The second case study is a different story. Republic of Korea is the main ally of Japan in the region. Their two common threats of North Korea and China are more than real and require immediate attention and close cooperation between the two countries plus the United States. Nevertheless, the burden of the past seems to be at the moment an extremely sensitive issue. The Japanese diplomacy has adopted an approach of denying new discussions on issues like Comfort Women and other historical incidents, considering them officially resolved. The Takeshima territorial dispute could also escalate rapidly. Japan is not recognizing a dispute at the area while South Korea, driven mainly by the public emotion of the mass, is acting as the islands are its own territory confronting Japan directly.

Finally, the Japanese diplomacy in Asia is also focusing on promoting its values and its influence mainly by economic means. Japan always saw itself as the responsible power to lead the region and as a bridge between West and Asia, being the example of economic development and prosperity. The XXI century has changed this reality. Historical challenges must be resolved and the Japanese diplomacy must show adaptability and flexibility given the fact that it is per se constrained due to the incapability of Japan of being a strong military power. Given the current situation and how the regional affairs are evolving, the status quo will, at a large extent, remain unchanged as well as the main trends of the Japanese diplomacy. The future though is unpredictable and more potential aggressiveness in the region will oblige the Japanese foreign policy to adapt and find solutions in unpleasant topics. at 


\section{REFERENCES}

1. Japanese Ministry of Foreign Affairs. 2010. "Diplomatic Book 2010."Accessed March 11. https://www.mofa.go.jp/policy/other/bluebook/2010/pdfs/chapter2.pdf.

2. Japanese Ministry of Foreign Affairs. 2016. "Diplomatic Book 2016." Accessed March 11.https://www.mofa.go.jp/files/000177713.pdf.

3. Japanese Ministry of Foreign Affairs. 2019. "Diplomatic Book 2019." Accessed March 12. https://www.mofa.go.jp/policy/other/bluebook/2019/html/chapter1/c0102.html.

4. Kawashima, Shin. 2017. "45 years of normalized Sino - Japanese diplomacy." The Diplomat, September 11. Accessed February 20, 2020. https://thediplomat.com/2017/09/45-years-ofnormalized-sino-japanese-diplomacy/.

5. Kazuo, Ogura. 2015. Japan's Asian Diplomacy. Tokyo: International House of Japan.

6. Kimura, Kan. 2019. The Burden of the Past: Problems of Historical Perception in Japan-Korea Relations. United States of America: Michigan University Press.

7. McCurry, Justin. 2010. "Japan-China row escalates over fishing boat collision." The Diplomat, September 9. Accessed March 10, 2020. https://www.theguardian.com/world/2010/sep/09/japan-china-fishing-boat-collision.

8. Meyer, Claude. 2010. China or Japan: Which will lead Asia? Paris: Presses de Sciences Po.

9. Penn, Michael. 2014. Japan and the War on Terror. New York: Palgrave Macmillan.

10. Prime Minister of Japan and his Cabinet. 2013. "Pledge for everlasting peace." Accessed April 19. http://japan.kantei.go.jp/96 abe/statement/201312/1202986 7801.html.

11. Ryall, Julian. 2019. "How Japan is using an old German map to irk South Korea." Deutsche Welle, March 27. Accessed March 10, 2020. https://www.dw.com/en/how-japan-is-using-anold-german-map-to-irk-south-korea/a-48078274.

12. Scalapino, Robert. 1977. The Foreign Policy of Modern Japan. California: University of California Press.

13. Somcynsky, Micheline B., and Cook Chris. 1999. Japan's System of Official Development Assistance. Canada: International Development Research Centre.

14. Wan, Ming. 2016. Understanding Japan-China Relations: Theories and Issues. Singapore: World Scientific Publishing.

15. Wijaya, Trissia, and Yuma Osaki. 2019. "Is This a True Thaw in Sino-Japanese Relations?" The Diplomat, February 16. Accessed March 19, 2020. https://thediplomat.com/2019/02/is-this-atrue-thaw-in-sino-japanese-relations/.

16. Yamasaki, Yoshiko. 2016. "The Creation of a Basis for the Possession of Takeshima by the Korean Government." Japan Digital Library, March 10. Accessed March 25, 2020. http://www2.jiia.or.jp/en/pdf/digital library/japan s territories/160414 Yoshiko Yamasaki.pdf.

17. Yasunori, Arano. 2013. "Foreign Relations in Early Modern Japan: Exploding the Myth of National Seclusion." Nippon, January 18. Accessed March 28, 2020. https://www.nippon.com/en/features/c00104/foreign-relations-in-early-modern-japanexploding-the-myth-of-national-seclusion.html. 